\title{
PENERAPAN MODEL MIND MAPPING UNTUK MENINGKATKAN KEMAMPUAN BERPIKIR KREATIF MATEMATIS SISWA MTs
}

\author{
SUSI AGUSTINI, SUMPENA ROHAENDI, MARIAM AR RAHMAN \\ Pendidikan Matematika FKIP Universitas Subang
}

agustini.susi@yahoo.com

\begin{abstract}
ABSTRAK
Penelitian ini dilatarbelakangi oleh masih rendahnya kemampuan berpikir kreatif matematis siswa dan permasalahan yang dihadapi siswa tidak berani dan malu. Hal ini dibuktikan dengan sering dijumpai beberapa masalah antara lain : (1) siswa tidak memiliki inisiatif bertanya, (2) sibuk menyalin tulisan dipapan tulis, dan (3) kurangnya elaborasi dalam kegiatan berkelompok. Tujuan penelitian ini bertujuan mengetahui perbedaan kemampuan berpikir kreatif matematis siswa dalam belajar matematika pada kelas yang diajarkan dengan model pembelajaran mind mapping dan kelas yang diajarkan dengan metode ekspositori. Metode dalam penelitian ini yaitu menggunakan kuasi eksperimen.Populasi dalam penelitian ini adalah siswa MTs negeri 3 Subang. Hasil penelitian menunjukan bahwa peningkatan kemampuan berpikir kreatif matematis siswa yang menggunakan model pembelajaran mind mapping lebih baik dari pada yang menggunakan pembelajaran ekspositori.
\end{abstract}

Kata Kunci: Kemampuan Berpikir Kreatif Matematis, Model Pembelajaran Mind Mapping.

\section{PENDAHULUAN}

Pendidikan merupakan salah satu kebutuhan pokok dalam kehidupan manusia. Di era globalisasi saat ini, Indonesia harus mampu meningkatkan mutu pendidikan, sehingga tidak kalah bersaing dengan negara lain. Secara umum pendidikan berfungsi untuk membangun watak dan perabadan suatu bangsa sesuai dengan isi Permendiknas no. 22 tahun 2006 yang berbunyi tentang Standar Isi Pendidikan Dasar dan Menengah. Peraturan ini sebagai wujud implementasi Undang-Undang No. 20 Tahun 2003 tentang Standar Pendidikan Nasional.

Matematika adalah simbol ilmu deduktif yang tidak menerima pembuktian secara induktif, ilmu tentang pola keteraturan dan stuktur yang terorganisasi, matematika juga merupakan salah satu pintu gerbang bekal untuk melihat teraturnya proporsi dan relasi di alamini (Heruman, 2007) dalam hal ini keterkaitan ilmu deduktif terhadap kemampuan berpikir kreatif yaitu untuk melihat macammacam kemungkinan penyelesaian terhadap suatu masalah.

Salah satu tujuan umum pembelajaran matematika pada intinya adalah agar siswa memiliki kemampuan-kemampuan/kompetensi yang diharapkan dalam 
pembelajaran matematika. Matematika merupakan "Queenand Servant of Science" Ruseffendi (dalam Sutrisno, 2011), maksudnya adalah Matematika selain sebagai pondasi bagi ilmu pengetahuan lain juga sebagai pembantu bagi ilmu pengetahuan yang lain, khususnya dalam pengembangan ilmu pengetahuan tersebut. Kline (dalam Saputra, 2012) menyatakan bahwa matematika itu bukan pengetahuan yang berdiri sendiri tetapi keberadaannya untuk membantu manusia dalam memahami dan menguasai permasalahan ekonomi, sosial dan alam.

Metode yang digunakan dalam pembelajaran mempunyai salah satu peran penting dalam pembelajaran. Pembelajaran tanpa metode tidak akan mencapai tujuan yang diinginkan, untuk itu metode merupakan upaya untuk mengimplementasikan rencana yang sudah dalam kegiatan nyata agar tujuan yang telah disusun tercapai secara optimal (Muchit, 2010). Selain itu juga dengan belajar matematika diharapkan siswa dapat memanfaatkan matematika untuk berkomunikasi dan mengemukakan gagasan.

Menurut Fraenkel (Tarwin, 2005) tahapan berpikir terdiri dari.

1. Tahapan berpikir konvergen, yaitu tahapan berpikir yang mengorganisasikan informasi atau pengetahuan yang diperoleh untuk mendapatkan jawaban yang benar.

2. Tahapan berpikir divergen, yaitu tahapan berpikir dimana kita mengajukan beberapa alternatif sebagai jawaban.

3. Tahapan berpikir kritis

4. Tahapan berpikir kreatif, yaitu tahapan berpikir yang tidak memerlukan penyesuaian dengan kenyataan.

Dari penjelasan di atas, dapat disimpulkan bahwa kemampuan berpikir kreatif merupakan kemampuan yang penting dalam pembelajaran matematika, karena matematika merupakan aktivitas sosial yang melibatkan interaksi aktif, di mahasiswa harus menerima ide-ide melalui mendengar, membaca, menelaah, dan membuat visualisasi, serta dapat mengungkapkan bahan konkrit.

Evans (1991) menjelaskan bahwa kemampuan berpikir kreatif adalah suatu aktivitas mental untuk membuat hubungan-hubungan (conection) yang terus menerus (kontinu), sehingga ditemukan kombinasi yang benar atau sampai seorang menyerah. Tak dapat dipungkiri, bahwa pembelajaran matematika disekolah sangat teoritik. Proses pembelajaran biasanya dimulai dengan penjelasan konsep disertai contoh, dilanjutkan dengan mengerjakan latihan soal-soal matematika. Oleh karena itu, perlu adanya upaya untuk meningkatkan kemampuan berpikir kreatif matematis siswa. Salah satu upaya yang dapat dilakukan dengan menggunakan model pembelajaran yang tepat.

\section{METODE PENELITIAN}

Berdasarkan pada permasalahan yang diteliti, metode yang digunakan adalah metode penelitian kuantitatif dan dalam penelitian ini menggunakan metode quasi eksperimen, dimana kelas yang satu mendapat pembelajaran dengan menggunakan model mind mapping dan kelas lain mendapat pembelajaran ekspositori (ceramah bervariasi) pada awal dan akhir pembelajaran kedua kelas diberi tes. 
Penelitian ini bertujuan untuk melihat pengaruh model pembelajaran mind mapping dalam meningkatkan kemampuan berpikir kreatif matematis belajar siswa. Pengaruh pembelajaran tersebut dilihat dengan cara membandingkan kemampuan berpikir kreatif matematis belajar siswa pada kelas eksperimen dan kelas kontrol.

Penelitian ini dilaksanakan di MTs Negeri 3 Subang yang berlokasi di Jl. Irian No. 02 Kasomalang Wetan Kecamatan Kasomalang Kabupaten Subang pada semester genap tahun ajaran 2018/2019. Penelitian ini dilaksanakan pada tanggal 06 sampai 26 Januari 2019 selama 6 kali pertemuan untuk kelas eksperimen dan kelas kontrol. Populasi penelitian ini adalah seluruh siswa MTs Negeri 3 Subang kelas VIII dan sampel penelitian ini adalah kelas VIII MTs Negeri 3 Subang dengan mengambil sampel dua kelas sebanyak 62 siswa dimana terdiri dari 32 siswa kelas VIII E sebagai kelas eksperimen dan 32 siswa kelas VIII C sebagai kelas kontrol.

Variabel bebas dalam penelitian ini adalah model pembelajaran mind mapping, sedangkan variabel terikatnya adalah kemampuan berpikir kreatif matematis.

Adapun desain penelitian yang digunakan dalam penelitian ini adalah the non equivalent pretest-posttest design, desain ini hampir sama dengan the randomized pretest-posttest control group design. Teknik pengacakan yang dilakukan pada desain ini menggunakan cluster random sampling/acak kelas.

\section{HASIL PENELITIAN DAN PEMBAHASAN}

\section{Analisis peningkatan kemampuan berpikir kreatif matematis}

Hasil analisis data peningktan kemampuan berpikir kreatif matematis siswa kelas eksperimen dan kelas kontrol terdiri dari data pretes, data uji normalitas. Uji homogenitas, uji perbedaan dua rerata yang tertuang pada tabel 1 berikut.

Tabel 1. Deskriptif Nilai Pretes dan Postes Kemampuan Berpikir kreatif

\begin{tabular}{|l|l|l|l|}
\hline Tes & $\mathbf{N}$ & Kelas Eksperimen & Kelas Kontrol \\
\hline Pretes & 32 & 6,06 & 5,05 \\
\hline Postes & 32 & 12,41 & 11,32 \\
\hline
\end{tabular}

Berdasarkan tabel 2 diatas terlihat bahwa rerataan skor pretes kelas eksperimen 6,06 dan rerataan kelas kontrol adalah 5.05. Sedangkan rerataan skor postes kelas eksperimen 12,41 dan rerataan kelas kontrol adalah 11,32. Uji statistik yang diujikan adalah uji normalitas, homogenitas dan uji perbedaan dua rerata. 
Tabel 2. Uji Normalitas Skor Pretes dan Postes kemampuan berpikir kreatif Matematis

\begin{tabular}{|l|l|l|}
\hline \multicolumn{1}{|c|}{ Hasil } & \multicolumn{1}{|c|}{ Kelas } & \multicolumn{1}{c|}{ Sig. } \\
\hline \multirow{2}{*}{ Pretes } & Eksperimen & 0,054 \\
\cline { 2 - 3 } & Kontrol & 0,317 \\
\hline Postes & Eksperimen & 0,494 \\
\cline { 2 - 3 } & Kontrol & 0,055 \\
\hline
\end{tabular}

Berdasarkan tabel 2 di atas maka dapat disimpulkan bahwa data berdistribusi normal, maka selanjutnya dilakukan uji homogenitas. Berikut hasil pengujian uji homogenitas dapat dilihat pada tabel 3 dibawah ini.

Tabel 3. Uji Homogenitas Pretes dan Postes Kemampuan berpikir kreatif Matematis

\begin{tabular}{|l|l|l|}
\hline \multicolumn{1}{|c|}{ Hasil } & \multicolumn{1}{|c|}{ Kelas } & \multicolumn{1}{c|}{ Sig. } \\
\hline Pretes & Eksperimen & \\
\cline { 2 - 2 } & Kontrol & \\
\hline Postes & Eksperimen & 0,201 \\
\cline { 2 - 2 } & Kontrol & \\
\hline
\end{tabular}

Berdasarkan tabel 4 di atas terlihat bahwa nilai signifikansi kelas eksperimen dan kelas kontrol lebih besar 0,05 artinya sampel kedua varians sama, selanjutnya dilakukan uji perbedaaan dua rerata dengan uji-t.

Berikut hasil uji perbedaan dua rerata dapat dilihat pada tabel 4 di bawah ini.

Tabel 4. Hasil Uji Perbedaan Dua Rerata Pretes dan Postes Kemampuan Berpikir Kreatif Matematis

\begin{tabular}{|l|l|l|}
\hline \multicolumn{1}{|c|}{ Hasil } & \multicolumn{1}{|c|}{ Kelas } & \multicolumn{1}{c|}{ Sig. } \\
\hline \multirow{2}{*}{ Pretes } & Eksperimen & 0,066 \\
\cline { 2 - 3 } & Kontrol & 0,066 \\
\hline Postes & Eksperimen & 0,243 \\
\cline { 2 - 3 } & Kontrol & 0,243 \\
\hline
\end{tabular}


Berdasarkan tabel 4 di atas terlihat bahwa pada pretes dan postes ini signifikansi nilai kelas eksperimen dan kelas kontrol lebih besar dari 0,05 artinya data pretes maupun postes kelas eksperimen yang mendapat model pembelajaran mind mappping dan kelas kontrol yang mendapat pembelajaran ekspositori memiliki perbedaaan rata-rata.

Untuk menghitung apakah peningkatan kemampuan berpikir kreatif matematis kelas eksperimen yang menggunakan model pembelajaran mind mapping lebih baik daripada kelas kontrol yang menggunakan model pembelajaran ekspositori, dengan menghitung indeks gain. Berikut perhitungan indeks gain tertuang pada tabel 5 di bawah ini.

Tabel 5. Deskripsi Indeks Gain Kemampuan Berpikir Kreatif Matematis

\begin{tabular}{|c|c|c|c|c|c|c|}
\hline \multirow[t]{2}{*}{ Kelas } & \multirow[t]{2}{*}{$\mathbf{N}$} & \multirow{2}{*}{$\begin{array}{c}\text { Rerata } \\
\text { Skor } \\
\text { Indeks } \\
\text { Gain }\end{array}$} & \multicolumn{2}{|c|}{ Uji Normalitas } & \multicolumn{2}{|c|}{ Uji Mann-Whitney } \\
\hline & & & $\begin{array}{l}\text { Shapiro- } \\
\text { Wilk }\end{array}$ & Ket & $\begin{array}{c}\text { Asym. } \\
\text { Sig } \\
\text { (2-tailed) }\end{array}$ & Ket \\
\hline $\begin{array}{c}\text { Eksperimen } \\
\text { (Model Mind } \\
\text { Mapping) }\end{array}$ & 32 & 2.1625 & 0,166 & \multirow[t]{2}{*}{ Normal } & \multirow[t]{2}{*}{0,0094} & $\begin{array}{l}\text { Terdapat } \\
\text { perbedaan } \\
\text { yang } \\
\text { signifikansi }\end{array}$ \\
\hline $\begin{array}{c}\text { Kontrol } \\
\text { (Ekspositori) }\end{array}$ & 32 & 2.1531 & 0,085 & & & \\
\hline
\end{tabular}

Berdasarkan tabel 6 di atas terlihat bahwa nilai signifikansi pada uji normalitas kelas eksperimen adalah 0,166 dan kelas kontrol adalah 0,085 kedua nilai $\geq 0,05$ jadi kedua nilai eksperimen dan kontrol berdistribusi normal.

\section{Analisis Angket Skala Sikap}

Analisis data kualitatif ini diperoleh dari hasil angket yang berisi tentang sikap siswa terhadap pembelajaran matematika dengan menggunakan model mind mapping. Angket skala sikap ini diisi oleh 32 orang siswa pada kelas eksperimen dipertemuan terakhir. Angket terdiri dari 15 pertanyaan, terbagi dalam pernyataan positif dan pernyataan negatif. Dari 32 siswa yang mengisi angket tersebut sebagian besar siswa memberikan sikap yang positif terhadap pembelajaran matematika dengan menggunakan model mind mapping. Analisis data angket adalah sebagai berikut pada tabel 6 . 
Tabel 6. Data Rekapitulasi Hasil Perhitungan Skala Sikap Siswa

\begin{tabular}{|c|c|c|c|c|c|c|c|}
\hline \multirow{2}{*}{ Variabel } & \multicolumn{7}{|c|}{ Persentase } \\
\hline & Pertanyaan & & No & SS & $\mathbf{S}$ & ST & STS \\
\hline \multirow{10}{*}{$\begin{array}{l}\text { Sikap siswa } \\
\text { terhadap } \\
\text { model Mind } \\
\text { Mapping }\end{array}$} & \multirow{5}{*}{ Positif } & & 2 & 65,6 & 31,3 & 3,1 & 0 \\
\hline & & & 3 & 43,8 & 50 & 6,2 & 0 \\
\hline & & & 5 & 21,9 & 75 & 3,1 & 0 \\
\hline & & & 7 & 49,6 & 53,1 & 0 & 0 \\
\hline & & & 9 & 37,5 & 43,7 & 15,7 & 3,1 \\
\hline & & Rata-rata & & 35,9 & 42,2 & 4,7 & 0,5 \\
\hline & \multirow{4}{*}{ Negatif } & & 1 & 9,4 & 6,2 & 75 & 9,4 \\
\hline & & & 4 & 6,2 & 31,2 & 46,9 & 15,7 \\
\hline & & & 6 & 0 & 21,9 & 75 & 3,1 \\
\hline & & & 8 & 0 & 37,5 & 62,5 & 0 \\
\hline & & Rata-rata & & 3,9 & 24,2 & 64,8 & 7,03 \\
\hline \multirow{8}{*}{$\begin{array}{l}\text { Sikap siswa } \\
\text { dalam } \\
\text { membangun } \\
\text { kemampuan } \\
\text { berpikir } \\
\text { kreatif }\end{array}$} & \multirow{4}{*}{ positif } & & 10 & 62,5 & 34,4 & 3,1 & 0 \\
\hline & & & 11 & 18,7 & 59,5 & 18,7 & 3,1 \\
\hline & & & 14 & 28,1 & 56,3 & 12,5 & 3,1 \\
\hline & & & 15 & 21,9 & 65,6 & 3,1 & 9,4 \\
\hline & & Rata-rata & & 26,3 & 43,1 & 7,5 & 3,1 \\
\hline & \multirow{2}{*}{ Negatif } & & 12 & 25 & 6,3 & 43,7 & 25 \\
\hline & & & 13 & 3,1 & 31,3 & 40,6 & 25 \\
\hline & & Rata-rata & & $\begin{array}{c}14,0 \\
6\end{array}$ & 18,8 & 42,2 & 25 \\
\hline
\end{tabular}

Berdasarkan tabel diatas dapat dideskripsikan bahwa rata-rata untuk pernyataan positif terhadap pembelajaran matematika dengan menggunakan model mind mapping $78,1 \%$ menyatakan sangat setuju dan setuju, dan 5,2\% menyatakan tidak setuju dan sangat tidak setuju. Artinya siswa memiliki respon positif terhadap pembelajaran matematika dengan menggunakan model mind mapping.

Rata-rata untuk pernyataan negatif terhadap pembelajaran matematika dengan menggunakan model mind mapping $28 \%$ menyatakan sangat setuju dan setuju, dan $71,83 \%$ menyatakan tidak setuju dan sangat tidak setuju. Artinya siswa memiliki respon positif terhadap pembelajaran matematika dengan menggunakan model mind mapping.

Deskripsi rata-rata sikap siswa untuk pernyataan positif dalam membangun kemampuan berpikir kreatif 69,4\% menyatakan sangat setuju dan setuju, dan 10,6\% menyatakan tidak setuju dan sangat tidak setuju. Artinya siswa memiliki respon positif terhadap membangun kemampuan berpikir kreatif.

Rata-rata sikap siswa untuk pernyataan negatif dalam membangun kemampuan berpikir kreatif 32,86\% menyatakan sangat setuju dan setuju, dan 67,2\% menyatakan tidak setuju dan sangat tidak setuju.Artinya siswa memiliki respon positif terhadap membangun kemampuan berpikir kreatif. 
Dari hasil persentase yang diperoleh dapat disimpulkan bahwa sikap siswa terhadap pembelajaran matematika dengan menggunakan model mind mapping dalam membangun berpikir kreatif dapat dinyatakan positif/baik.

\section{KESIMPULAN DAN SARAN}

\section{A. Kesimpulan}

Berdasarkan hasil penelitian dan pembahasan mengenai pembelajaran matematika dengan model mind mapping untuk meningkatkan kemampuan berpikir kreatif matematis siswa dan sikap siswa terhadap model mind mapping yang dilakukan, maka diperoleh kesimpulan sebagai berikut.

1. Dari hasil analisis yang dilakukan bahwa siswa yang memperoleh pembelajaran mind mapping memiliki peningkatan kemampuan berpikir kreatif matematis yang lebih baik daripada siswa yang memperoleh pembelajaran ekspositori.

2. Sikap siswa merespon positif terhadap pembelajaran matematika dengan menggunakan model mind mapping. Selama proses pembelajaran siswa merasa lebih senang dan aktif. Siswa juga merasa lebih mudah untuk memahami materi dengan sistem diskusi kelompok.

\section{B. Saran}

Berdasarkan hasil penelitian, pembahasan dan kesimpulan yang ada, maka ada beberapa saran yang akan disampaikan sebagai berikut.

1. Kemampuan berpikir kreatif sangat penting untuk dimiliki oleh siswa karena sangat bermanfaat baik dalam pembelajaran maupun dalam kehidupan sehingga diperlukan pembelajaran yang dapat melatih dan meningkatkan kemampuan berpikir kreatif.

2. Dalam upaya meningkatkan kemampuan berpikir kreatif matematis siswa, ada baiknya guru mencoba menerapkan pembelajaran melalui model mind mapping dalam proses belajar mengajarnya.

3. Untuk lebih mengembangkan kemampuan berpikir kreatif matematis siswa, maka disarankan pemberian soal harus lebih bervariasi dan terarah dalam kehidupan sehari-hari agar lebih mudah dipahami siswa.

\section{DAFTAR PUSTAKA}

Depdiknas. (2004). Perkembangan Bidang Teknologi Inpormasi dan Komunikasi. Jakarta

Evans. (1991), kemampuan berpikir kreatif. [Online]. Tersedia:

Heruman. (2007). Model Pembelajaran Matematika. Bandung: Rosda

Muchit. (2010). Pembelajaran tanpa metode tidak akan mencapai tujuan yang diinginkan. [Online]. Tersedia: http//wordpress.com/peran-pentingmetode-pembelajaran.html. [27 mei 2017] 
Saputra. (2012). Berpikir dan Disposisi Matematika: Apa, Mengapa, dan Bagaimana dikembangkan pada Peserta Didik. FPMIPA UPI. [Online]. Tersedia: Http://id.scribd.com/doc/76353753/Berpikir-dan-DisposisiMatematika-Utari [27 mei 2017]

Sutrisno. (2011).penilaian pendidikan dan hasil belajar siswa khususnya dalam pengajaran matematika untuk guru dan calon guru. Bandung: Tarsito

Tarwin. Y. W. (2005). Upaya Meningkatkan Kemampuan Berpikir Kreatif Siswa Dalam Pembelajaran Matematika. Skripsi. Jurusan Pendidikan Matematika FPMIPA UPI. Tidak Diterbitkan.

Undang-undang No. 20 Tahun 2003 tentang Standar Pendidikan nasional. Lembaran Negara RI Tahun 2003, No. 56. Sekretariat Negara. Jakarta. 